\title{
PENGARUH PENGGUNAAN E-MODUL PENGOLAH ANGKA BERBASIS HYPERTEKS TERHADAP HASIL BELAJAR KKPI SISWA KELAS X SMK NEGERI 2 SINGARAJA
}

\author{
I Made Dika Anggara, Made Windu Antara Kesiman, Ketut Agustini \\ Jurusan Pendidikan Teknik Informatika \\ Universitas Pendidikan Ganesha \\ Email: dekndu@yahoo.com, eghee2006@gmail.com
}

\begin{abstract}
ABSTRAK
Penelitian ini bertujuan untuk (1) mengetahui pengaruh penggunaan e-modul pengolah angka berbasis hyperteks terhadap hasil belajar KKPI siswa kelas X SMK Negeri 2 Singaraja dan (2) mengetahui respon siswa tentang penggunaan e-modul pengolah angka berbasis hyperteks terhadap hasil belajar KKPI siswa kelas X SMK Negeri 2 Singaraja.

Penelitian ini merupakan penelitian eksperimen semu, dimana populasi dalam penelitian adalah siswa kelas X SMK Negeri 2 Singaraja dengan sampel penelitian siswa kelas X P4 dan X T2 SMK Negeri 2 Singaraja semester genap tahun ajaran 2010/2011 sebanyak 67 orang. Penelitian ini menggunakan rancangan Posttest-Only Control Design. Diakhir pembelajaran, kedua kelas sampel diberi tes kognitif dan tes psikomotor dengan menggunakan instrumen yang sama yang telah diuji secara kualitatif dan kuantitatif. Pengumpulan data dilakukan dengan metode tes pilihan ganda satu jawaban benar dan tes unjuk kerja. Metode tes dilakukan untuk memperoleh data nilai akhir setelah diberi perlakuan pada kelompok eksperimen dan kelompok kontrol, sebelum dianalisis dilakukan uji prasyarat yang meliputi uji normalitas dan uji homogenitas. Data dianalisis menggunakan uji t, sedangkan untuk respon siswa menggunakan metode angket.

Hasil penelitian ini menunjukkan adanya pengaruh yang signifikan terhadap hasil belajar siswa kelas X SMK Negeri 2 Singaraja pada mata pelajaran Keterampilan Komputer dan Pengelolaan Informasi (KKPI) antara siswa yang menggunakan e-modul pengolah angka berbasis hyperteks dengan siswa yang menggunakan modul pembelajaran konvensional. Hasil analisis uji-t memperoleh $t_{\text {hitung }}$ sebesar 8,263 dan $t_{\text {tabel }}$ sebesar 1,997 untuk dk sebesar 65 dengan taraf signifikan 5\%. Berdasarkan kriteria pengujian diperoleh $t_{\text {hitung }}>\mathrm{t}_{\text {tabel }}$, ini berarti $\mathrm{H}_{0}$ ditolak. Hasil analisis respon siswa menunjukkan respon positif dengan rata-rata nilai respon sebesar 77, terdapat 2 orang siswa memberikan respon sangat positif, 27 orang siswa memberikan respon positif dan 5 orang siswa memberikan respon cukup positif, sehingga dapat disimpulkan bahwa terdapat pengaruh yang signifikan penggunaan e-modul pengolah angka berbasis hyperteks terhadap hasil belajar KKPI siswa kelas X SMK Negeri 2 Singaraja dan terdapat respon yang positif dari siswa terkait penggunaan e-modul pengolah angka berbasis hyperteks dalam pembelajaran.
\end{abstract}

Kata-kata kunci : e-modul pengolah angka berbasis hyperteks, modul pembelajaran konvensional, hasil belajar. 
ISSN 2089-8673

Jurnal Nasional Pendidikan Teknik Informatika (JANAPATI)

Volume 1, Nomor 2, Juli 2012

\begin{abstract}
The purposes of this research are (1) To know about the effect of e-module processing a number of hypertext based toward KKPI learning result the $\mathrm{X}$ grade students at SMK Negeri 2 Singaraja (2) To know the response of the students toward emodule processing a number of hypertext based toward KKPI learning result the $\mathrm{X}$ grade students at SMK Negeri 2 Singaraja.

The type of this research is quasi-experimental research. The population of this research is the students of SMK Negeri 2 Singaraja with sample of this research of X P4 class and X T2 class in the second semester in 2010/2011 period many as 67 people. The research plan which is used in this research is Posttest-Only Control Design. At the end of the learning process both sample classes were given a cognitive tests and psychomotor tests using the same instrument that has been tested qualitatively and quantitatively. Data collecting was conducted by using a multiple choice test with a single true answer and test performance. Testing method was conducted to get the final mark after being given treatment toward the experimental group and the control group. Before being analyzed, pre-conditional test including normality test and homogeneity test had been done. Afterward, the data was analyzed using t test. Meanwhile, the response was tested using questionnaire method.

The result of this research shows that based on the analysis of the test, it is known that there is a significant effect toward the learning result of the $\mathrm{X}$ grade students at SMK Negeri 2 Singaraja in KKPI course among the students who are using e-module with hypertext-based processing a number of students who using conventional learning module. T-test analysis results obtained t count for 8.263 and 1.997 for dk ttable registration by 65 with $5 \%$ significance level. Based on testing criteria obtained tcount> ttable, this means that $\mathrm{HO}$ is rejected. Result analysis of student responses showed a positive response with an average response value of 77, there were 2 students gave very positive responses, 27 students gave a positive response and 5 students responded quite positively, so it can be concluded that there was a significant effect of using e -module processing a number of hypertext based on the results of class X students KKPI learning SMK Negeri 2 Singaraja and there is a positive response from students related to the use of e-module processing a number of hypertext-based learning.
\end{abstract}

Key words: e-module processing a number of hypertext-based, conventional learning module, learning result. 
ISSN 2089-8673

Jurnal Nasional Pendidikan Teknik Informatika (JANAPATI)

Volume 1, Nomor 2, Juli 2012

\section{Pendahuluan}

Pendidikan di Indonesia sekarang ini dapat diibaratkan seperti mobil tua yang mesinnya rewel dan sedang melintasi jalur lalu lintas di jalan bebas hambatan, pada satu sisi dunia pendidikan di Indonesia saat ini dirundung masalah yang besar dan pada sisi lain tantangan menghadapi milenium ketiga semakin besar. Dari sisi kualitas, pendidikan kita sangat memprihatinkan dibandingkan dengan kualitas pendidikan bangsa lain dan perlu diingat bahwa pendidikan memegang peranan penting dalam mencetak sumber daya manusia yang handal dan mampu mengembangkan kemampuan dan keterampilan untuk menyesuaikan diri dalam perkembangan ilmu pengetahuan, teknologi dan seni (IPTEKS) dewasa ini (Ferdy H.Pantar, 2009).

Guru sebagai barisan paling depan dalam rangka mencetak sumber daya manusia berkualitas, pada umumnya para guru menggunakan buku - buku pegangan atau modul ajar. Modul merupakan alat atau sarana pembelajaran yang berisi materi, metode, batasan-batasan, dan cara mengevaluasi yang dirancang secara sistematis dan menarik untuk mencapai kompetensi yang diharapkan sesuai dengan tingkat kompleksitasnya (Rosyid, 2010), penggunaan modul ajar sangatlah bermanfaat untuk mengatasi keterbatasan frekuensi tatap muka antara siswa dengan pengajar, dengan adanya modul ajar tersebut siswa dapat belajar secara mandiri. Belajar merupakan suatu proses aktif dalam memperoleh pengalaman atau pengetahuan baru sehingga timbul perubahan tingkah laku, misalnya setelah belajar seorang mampu mendemonstrasikan dan keterampilan dimana sebelumnya siswa tidak dapat melakukannya (Hudojo, 1987).

Seiring dengan kemajuan Teknologi Informasi (TI), dunia pendidikan senantiasa bergerak maju secara dinamis, khususnya untuk menciptakan media, metode dan materi pendidikan yang semakin menarik dan interaktif. Criticos (dalam Santyasa, 2007) menyatakan media merupakan salah satu komponen komunikasi, yaitu sebagai pembawa pesan dari komunikator menuju komunikan, sedangkan Sadiman (dalam Samsul, 2010) menyatakan media sebagai segala sesuatu yang dapat digunakan untuk menyalurkan pesan dan pengirim pesan kepada penerima pesan, sehingga dapat merangsang perasaan, perhatian, dan minat serta perhatian siswa sedemikian rupa, sehingga proses belajar mengajar berlangsung dengan efektif dan efesien sesuai dengan yang diharapkan. Sektor pendidikan kita harus mampu memanfaatkan Teknologi Informasi (TI) untuk mengembangkan sistem pendidikan berbasis media elektronik. 
Hasil wawancara dengan guru mata pelajaran KKPI kelas X untuk materi pengolah angka di SMK Negeri 2 Singaraja, bahwa selama ini siswa telah diberikan soal-soal latihan praktek dan modul ajar pengolah angka, tetapi kurang dari segi materi maupun contoh-contoh soalnya, disamping itu modul ajar konvesional kurang menarik perhatian siswa untuk dipelajari karena berupa buku cetak. Sebelumnya telah dilakukan penelitian pengembangan media pembelajaran yang berjudul pengembangan e-modul pengolah angka pada mata pelajaran Keterampilan Komputer dan Pengelolaan Informasi (KKPI) berbasis hyperteks untuk kelas X di SMK Negeri 2 singaraja. Hasil penelitian tersebut, respon siswa terhadap pengembangan e-modul ajar pengolah angka (Microsoft excel 2003) berbasis hyperteks ini berada pada kategori sangat positif dilihat dari rata-rata respon siswa yaitu 88.25, sedangkan untuk prosentasenya mencapai 95\% sangat positif, $5 \%$ positif, $0 \%$ cukup, $0 \%$ negatif dan $0 \%$ sangat negatif dan terdapat saran untuk mengembangkan penelitian ini menjadi penelitian eksperimen.

Berdasarkan uraian di atas, peneliti termotivasi untuk mengkaji lebih jauh apakah penggunaan e-modul pengolah angka pada mata pelajaran KKPI (keterampilan komputer dan pengelolaan informasi) berbasis hyperteks untuk kelas X di SMK Negeri 2 Singaraja berpengaruh terhadap hasil belajar siswa dalam penelitian yang berjudul “

Pengaruh Penggunaan E-Modul Pengolah Angka Berbasis Hyperteks Terhadap Hasil Belajar KKPI Siswa Kelas X SMK Negeri 2 Singaraja”.

\section{Metodelogi Penelitian}

Penelitian ini tergolong penelitian eksperimen semu dengan menggunakan desain penelitian “Posttest-Only Control Design” (Sugiyono, 2009), dimana terdapat dua kelas yaitu kelas eksperimen dengan jumlah siswa sebanyak 34 dan kelas kontrol dengan jumlah siswa sebanyak 33. Kelas eksperimen diberikan perlakuan berupa penggunaan e-modul pengolah angka berbasis hyperteks saat proses pembelajaran berlangsung dan diakhir pembelajaran kedua kelas diberikan tes akhir untuk mengetahui hasil belajar KKPI siswa.

Metode pengumpulan data yang digunakan dalam penelitian ini adalah metode tes dan angket. Metode tes digunakan untuk mengetahui hasil belajar KKPI siswa dengan menggunakan tes pilihan ganda dan tes unjuk kerja, sedangkan metode angket digunakan untuk mengetahui respon siswa terkait penggunaan e-modul pengolah angka 
berbasis hyperteks dalam proses pembelajaran dengan menggunakan angket respon siswa. Data yang diperoleh dalam penelitian ini adalah data kuantitatif dan kualitatif. Data kuantitatif akan dianalisis dengan analisis statistik deskriptif untuk mendeskripsikan data hasil belajar siswa, kemudian data kualitatif dianalisis dengan memberi makna terhadap deskripsi data. Analisis statistik yang akan digunakan berupa uji normalitas, uji homogenitas, dan uji hipotesis.

Uji normalitas dilakukan untuk mengetahui sebaran data hasil belajar KKPI pada kelas eksperimen dan kelas kontrol dengan menggunakan analisis Chi-Square (Sudijono, 2007) dan uji homogenitas dilakukan untuk mengetahui apakah varians kelompok eksperimen dan kelompok kontrol homogen atau sama dengan menggunakan uji F (Sudjana, 2005), sedangkan uji hipotesis dilakukan untuk mengetahui apakah hipotesis alternatif yang telah diajukan diterima atau ditolak dengan menggunakan rumus polled varians. Skor rata - rata respon siswa didapatkan dengan membagi jumlah skor respon siswa dengan jumlah siswa (Nurkancana dan Sunartana, 1992).

\section{Hasil Penelitian dan Pembahasan}

Analisis dari hasil penelitian memperoleh rata-rata post-test hasil belajar KKPI yang dicapai siswa pada kelas eksperimen sebesar 29,85, sedangkan rata-rata post-test hasil belajar KKPI untuk kelas kontrol sebesar 24,71. Berdasarkan hal tersebut, rata-rata post-test hasil belajar KKPI pada kelas eksperimen lebih besar dibandingkan dengan kelas kontrol.

Perhitungan normalitas dan homogenitas kedua kelas memiliki data yang normal dan homogen, berdasarkan uji normalitas yang telah dilakukan diperoleh bahwa distribusi data dari kedua kelas normal, dimana hasil perhitungan pada kelas eksperimen memperoleh $\mathrm{X}^{2}$ hitung sebesar 1,2147, sedangkan pada kelas kontrol memperoleh $\mathrm{X}^{2}$ hitung sebesar 1,4457 dengan $X^{2}$ tabel sebesar 11,070, karena $X^{2}{ }_{\text {hitung }}$ dari kedua kelas lebih kecil dari $\mathrm{X}^{2}$ tabel maka dapat dinyatakan bahwa distribusi data dari kedua kelas normal, sedangkan dari uji homogenistas yang telah dilakukan diperoleh bahwa varians antara kelas eksperimen dan kelas kontrol homogen, dimana diperoleh nilai $F_{\text {hitung }}$ sebesar 1,163 dengan $F_{\text {tabel }}$ sebesar 1,720, karena nilai $F_{\text {hitung }}$ lebih kecil dari $F_{\text {tabel }}$ maka dapat dinyatakan bahwa varians dari kedua kelas homogen. 
Setelah diketahui bahwa sebaran data pada kedua kelas normal, kemudian varians dari kedua kelas homogen dan jumlah siswa pada masing - masing kelas berbeda, maka dilakukan pengujian hipotesis menggunakan rumus polled varians dengan taraf signifikansi 5\% dan derajat kebebasan 65, dimana dari perhitungan tersebut memperoleh $t_{\text {hitung }}$ sebesar 8,263 dengan $t_{\text {tabel }}$ sebesar 1,997, karena $t_{\text {hitung }}$ lebih besar dari $t_{\text {tabel }}$ maka hipotesis alternatif yang telah diajukan diterima yang artinya terdapat pengaruh yang signifikan penggunaan e-modul pengolah angka berbasis hyperteks terhadap hasil belajar KKPI siswa kelas X SMK Negeri 2 Singaraja.

Besarnya hasil belajar KKPI kelas eksperimen yang menggunakan e-modul pengolah angka berbasis hyperteks diakibatkan karena siswa lebih mudah memahami materi pelajaran yang terdapat pada e-modul pengolah angka berbasis hyperteks, penyajian materi pada e-modul pengolah angka berbasis hyperteks lebih menarik dan beragam, tidak hanya berbentuk tulisan tapi penyajian materinya juga berbentuk video, sedangkan pada modul pembelajaran konvensional hanya menyajikan materi pelajaran dalam bentuk tulisan. Informasi atau materi pelajaran yang ditampilkan melalui suara, gambar, gerakan dan warna akan membuat perhatian siswa terpusat pada pembelajaran, sehingga siswa lebih mudah memahami materi pelajaran.

Respon siswa kelas XP4 SMK Negeri 2 Singaraja terhadap penggunaan e-modul pengolah angka berbasis hyperteks adalah positif dengan rata-rata nilai respon sebesar 77, terdapat 2 orang siswa memberikan respon sangat positif, 27 orang siswa memberikan respon positif dan 5 orang siswa memberikan respon cukup positif.

IV. Penutup

Berdasarkan perumusan masalah, tujuan penelitian, pengajuan hipotesis dan analisis data penelitian, maka dapat ditarik kesimpulan sebagai berikut: (1) Adanya pengaruh yang signifikan antara siswa yang pembelajarannya mengunakan e-modul pengolah angka berbasis hyperteks dengan modul pembelajaran konvensional pada siswa kelas X semester II SMK Negeri 2 Singaraja. Hal ini dapat dilihat dari hasil perolehan t hitung sebesar 8,263 sedangkan t tabel sebesar 1,997, dengan demikian $\mathrm{H}_{\mathrm{a}}$ diterima dan $\mathrm{H}_{0}$ ditolak, sehingga e-modul pengolah angka berbasis hyperteks berpengaruh secara signifikan terhadap hasil belajar KKPI siswa kelas X SMK Negeri 2 Singaraja; (2) Respon siswa kelas XP4 SMK Negeri 2 Singaraja terhadap penggunaan e-modul pengolah angka berbasis hyperteks adalah positif dengan rata-rata nilai respon 
sebesar 77, terdapat 2 orang siswa memberikan respon sangat positif, 27 orang siswa memberikan respon positif dan 5 orang siswa memberikan respon cukup positif.

Dari hasil penelitian yang diperoleh, maka peneliti memberikan saran-saran sebagai berikut : (1) Pihak sekolah diharapkan bersedia menggunakan e-modul pengolah angka berbasis hyperteks dalam proses pembelajaran sehingga mampu meningkatkan prestasi belajar siswa; (2) Hendaknya sekolah menyediakan sebuah speaker atau head-phone untuk menunjang pembelajaran menggunakan e-modul pengolah angka berbasis hyperteks karena selain bebentuk tulisan, penyajian materinya juga berbentuk video; (3) Bagi pihak sekolah, pihak lembaga terkait lainnya dan peneliti berikutnya diharapkan bisa mengadakan penelitian lanjutan dengan mengambil populasi yang lebih besar sehingga diperoleh simpulan yang lebih luas untuk semakin mengembangkan pembelajaran e-modul di Indonesia.

\section{Daftra Pustaka}

Ferdy H.Pantar. 2009. “Model Pembelajaran Kuantum”. http://sarkomkar.blogspot.com/2009/02/model-pembelajaran-quantumteaching.html

Hudojo. 1987. Belajar Mengajar. Jakarta: Departemen P dan K Direktorat Jenderal Pendidikan Tinggi.

Nurkancana dan Sunartana. 1992. Evaluasi hasil belajar. Surabaya: Usaha Nasional

Rosyid. 2010. "Pengertian, Fungsi dan Tujuan Penulisan Modul”. http://www.rosyid.info/2010/06/pengertian-fungsi-dan-tujuan-penulisan.html (diakses tanggal 5 Desember 2010).

Samsul. 2010. “Macam - Macam Media Pembelajaran”. http://www.unjabisnis.com/2010/06/macam-macam-media-pembelajaran.html (diakses tanggal 7 Oktober 2010).

Santyasa, I Wayan. 2007. “Landasan Konseptual Media Pembelajaran”. Makalah disajikan dalam Workshop Media Pembelajaran bagi Guru-Guru SMA Negeri Banjar Angkan, Fakultas Pendidikan Matematika dan Ilmu Pengetahuan Alam Universitas Pendidikan Ganesha, Banjar Angkan Klungkung 10 Januari 2007.

Sudijono, Anas. 2007. Pengantar Evaluasi Pendidikan. Jakarta: PT. Raja Grafindo Persada.

Sudjana. 2005. Penilaian Hasil Proses Belajar Mengajar. Bandung: Remaja Rosdakarya. 
ISSN 2089-8673

Jurnal Nasional Pendidikan Teknik Informatika (JANAPATI)

Volume 1, Nomor 2, Juli 2012

Sugiyono. 2009. Metode Penelitian Pendidikan Pendekatan Kuantitatif, Kualitatif, dan R\&D. Bandung: CV. ALFABETA. 